\title{
From individual to relational strategies: Transforming a manual-based psycho- educational course at school
}

\author{
Anette Wickström \\ Linköping University Post Print
}

Tweet

N.B.: When citing this work, cite the original article.

Original Publication:

Anette Wickström, From individual to relational strategies: Transforming a manual-based psycho-educational course at school, 2013, Childhood, (20), 2, 215-228.

http://dx.doi.org/10.1177/0907568212457094

Copyright: SAGE Publications (UK and US)

http://www.uk.sagepub.com/home.nav

Postprint available at: Linköping University Electronic Press

http://urn.kb.se/resolve?urn=urn:nbn:se:liu:diva-85164 
From individual to relational strategies: Transforming a manual-based psychoeducational course at school

\begin{abstract}
The present article focuses on 13-year-old girls' meaning-making processes during participation in a manual-based psycho-educational course at school. Drawing on childhood studies and ethnographic investigations of subjectivity, the author explores how the course is realized in practice. The analysis, based on video-recordings of 13 classes, shows that the girls and the teachers, through collective transformation, moves the focus from individual potential problems to relational issues. The results demonstrate the weakness of using manual-based educational courses, and indicate that cognitive methods for dealing with negative thoughts could be replaced by exercises designed to deal with interaction and strengthening the individual.
\end{abstract}

\title{
Keywords
}

intersubjective experiences, manual-based course, psycho-educational intervention, subjectivity, video-recordings

\section{Introduction}


Ever since public health became institutionalized as a new concept in Sweden in the 1930s, the goal has been to get each individual to make health a basic principle in his/her way of life. Health campaigns targeted identified risk groups, and children was the focus of observation and measures (Johannisson, 1997: 235). The comprehensive school, a vital part of building up the Swedish welfare state, became a site for preventive health programs. Today, according to Löf (2011), the field of school in Sweden appears to be colonized by a public health discourse.

Contemporary international discourses focus on 'a crisis' in children's mental health and the need for emotional literacy (Orbach, 1999). Policy-makers and Government authorities in industrialized countries invest in policy initiatives and courses aimed at promoting children's mental health (Coppock, 2011; Hoffman, 2009; Wishart et al., 2006; Dahlstedt et al. 2011). Although a clear majority of young people report good mental health, efforts to promote children's mental health and emotional wellbeing have largely been developed as universal and preventive interventions in the schools (Coppock, 2011). As a result numerous pedagogical programs have been marketed, such as Social emotional learning (SEL), which aims to teach all students fundamental social and emotional competencies (Hoffman, 2009). In Sweden a specific subject called Life Competence Skill has been developed in which courses on emotional learning may be included (Löf, 2011). Other interventions promoted in the schools to reduce the risk of depressive disorders in children and adolescents are psycho- 
educational courses (Merry et al., 2009). However, critical research has shown that such courses pathologize young people, labeling them as 'at risk' and making mental problems a question of individual deficiencies (Coppock, 2011; Dahlstedt et al., 2011). The present article focuses on school girls participating in a manual-based psychoeducational course called 'Depression in Swedish Adolescents' (DISA) (Lindberg et al., 1995). The aim is to understand how the girls experience the course and help to shape how the classes are realized, and in this way to advance our knowledge of what happens in practice. Moreover, it aims to discuss what this knowledge tells us about manualbased courses as such.

\section{DISA}

DISA is based on an American course called CWS, 'the Adolescent Coping With Stress course' (Lindberg et al. 1995, see also Clarke and Lewinsohn, 1995), which in its turn is a development of a form of cognitive behavioral therapy (CBT) used in clinical contexts to treat teenagers suffering from depression or depressive symptoms (Clarke et al., 1990). In Sweden, however, the intervention is intended to be a preventive measure rather than a treatment, and it targets groups of school girls irrespective of their psychological health. The reason for targeting girls is because, in a comprehensive survey carried out in 2009, Swedish girls reported more mental ill health than boys did (Swedish National Institute of Public Health, 2011). In the users' manual, the title does not include the word depression. DISA is then used as a Swedish acronym for 'Activate 
Your Inner Strength'. The contrast between the two different names for DISA is mirrored in the contradiction that the course stems from CBT for individual adolescents with depressive symptoms, but is used as a universal preventive intervention for groups of adolescents.

In most schools, participation in DISA is mandatory for teenage girls, while there is no similar course for boys. DISA consists of ten classes but is often extended due to the difficulty finding time for all the exercises. The participants are given a workbook or handouts with 85 exercises consisting of comic strips to be analyzed, thought diagrams and mood diaries to be filled in, lists of 'common negative or positive thoughts' to choose from, lists of unreasonable thoughts and thought traps to adjust, and homework aimed at registering thoughts. The group leader's manual states that the aim of the method is to give an overview of depressive symptoms and to teach adolescents cognitive methods for identifying and dealing with irrational or negative self-concepts and thoughts that are believed to contribute to the development of depressive symptoms. 63 of the 85 exercises in the manual encourage participants to register their negative or unreasonable thoughts, which are presented as something they should work to rid themselves of. By contrast, only seven of the exercises concern registering something positive. The course is supposed to help adolescents turn the negative into something positive, and the starting point in this process involves identifying the negative. 
The DISA manual was adapted to Swedish conditions by the Knowledge Centre for Health Issues in the Stockholm County Council (Lindberg 2011). Their evaluation showed that participants in DISA had significantly lower self-assessed sub-syndrome symptoms than did girls in the control group (Treutiger 2006), and these findings have been used to support implementation of DISA in the Swedish schools. However, the Swedish Council on Health Technology Assessment (SBU), which is commissioned by the Swedish Government to evaluate health care technologies, concludes that other studies show conflicting results and that such effects are either insignificant or absent (SBU 2010). Moreover, how the course has been realized in practice was not measured (Jablonska and Heinemans, 2011). Thus, qualitative studies can complete the picture. Here, girls as target groups are studied from the user perspective and the focus is on the interaction between the girls, the teacher and the course. To my knowledge, this is the first study of its kind, that is, a study based on video recordings of a manual-based course carried out at school.

\section{Agency and intersubjective experiences}

The present study is part of a research project on public health courses in the schools, a project whose starting point is an interest in children's perspectives and related to the broad field of interdisciplinary childhood studies elaborated below (Zetterqvist Nelson 2011). Children's perspective may be associated with research focused on children's social conditions seen through statistics and documents, as well as with research that 
involves collecting information from the children themselves. To distinguish between these two approaches, Halldén (2003) defines them as the child perspective and the children's perspective, respectively. The children's perspective focuses specifically on children as social actors, and ethnographic studies have played a prominent part in following children's perspective when they participate and interact in daily life. However, this does not guarantee that children's voices will be heard. All ethnographical descriptions are the author's description; reality is simplified in order to communicate it and the meaning is socially constructed (James, 2007). Therefore, 'an attitude of methodological immaturity' is useful, not in the sense of a weakness but a potential to see the researcher as someone seeking knowledge (Wickström, 2008; Gallacher and Gallagher, 2008). For me, this involved returning to the field one year after the course to get feedback on my analysis (see page 10). Also useful is the principle of ethical symmetry which widens questions of ethics to be 'part of the ongoing, everyday process of the research' (Christensen and Prout 2002: 493). In the present study, I did not only negotiate access and permission but always tried to give the participants a choice. I constantly communicated with the teachers to avoid conflicts between research ethics and local ethical guidelines. When done with care, Allison James argues (2007: 267), explorations of children's perspectives can allow us to give indirect voice to children, theorize about their experiences and speak to issues of social and political change. 
The present article starts from a theoretical understanding of the notion that children and young people negotiate complex social worlds as they participate in these worlds.

Children are social actors that take part in constructing, for example, their classroom community; they are not merely passive recipients of information. At the same time, children and young people are subject to surveillance and social regulation, and their possibility to take action is dependent on tangible resources and the adults around them. Thus, positioning children as agents involves considering the particularity of specific children and local worlds, while bearing in mind structural influences that both constrain and enable children's agency (James, 2010).

Girls participating in a psycho-educational course are influenced by their school context, their teachers and the intervention. At the same time, the girls and their activities bring about social change, because the girls participate on their own terms. They both reproduce social norms and have the potential to disrupt them (cf. Valentine, 2011). In subjectivity-oriented theory, power and meaning are not seen as being in theoretical opposition, but as being intimately linked (Kleinman and Fitz-Henry, 2007). Participating in a course at school includes a meaning-making process and at the same time involves the subtle forms of power that permeate life at school; it is 'both a strategy of existence and a material and means of governance' (Biehl et al., 2007). Experience is seen as intersubjective; experiences involve practices, negotiations and contestations with others with whom we are associated (Kleinman and Fitz-Henry, 
2007). People have access to the world through embodied practices, for example activities associated with growing up and attending school. Experience is thus grounded in collective symbols and interaction, realities that individuals continuously reinterpret and transform. In my analysis, I am interested in the DISA course as a practice, where participants actively engage in and negotiate the meanings of the various course elements. My interest is also aimed at instances of contestation and opposition with regard to the course and the teachers.

\section{Strategically situated ethnography}

At the beginning of January 2011, I joined a meeting for 16 girls who were interested in knowing more about DISA. The 13-year-old girls were attending a nine-year compulsory school in a small town in central Sweden. Two teachers who are trained DISA leaders ${ }^{\mathrm{i}}$ presented the course and the possibility to voluntarily participate in DISA instead of joining classmates in ordinary lessons in the subject called Life Competence Education. The girls also received information about the research project under way and were told they could choose between two courses, one of which was part of the research project. I explained my role, the concept of confidentiality and informed consent, and my interest in the girls' own experiences of DISA. ${ }^{\text {ii }}$ Seven girls chose to join the study group, and on January 25 they started and continued with 13 one-hour classes, which ran until May 24. The educational authorities as well as the staff considered DISA a 
useful tool, which legitimated the teachers and the girls occupying the only room available for group activities.

All 13 classes were video-recorded, using two cameras on tripods, in order to document social interplay in everyday practices, especially non-verbal actions and expressions (Heath et al., 2010). Apart from two occasions when I was prevented from coming, I sat in the room, observed what was going on and wrote field notes. Only on rare occasions did I interact with the group, for instance when one of the girls offered me a piece of the cake she had brought. Nevertheless, the girls kept an eye on me and the cameras and sometimes displayed so-called camera behaviors, such as looking into the cameras (Duranti 1997). When I was absent, they asked the teacher where I was, checked whether the cameras were running and 'flipped out' for a while in front of them. The fact that I was sitting in the room and that the cameras were running affected the course in different ways that I can only speculate about. The teachers were eager to have good, productive classes, and they sometimes prepared the girls for the next class when they met them in the corridor. The girls, for their part, were the object of a great deal of attention, and perhaps some of them felt obliged to participate because they had chosen the research group. However, one of the seven girls chose to leave after a while, opening up that possibility for the others.

Studying only one among many other school activities, like I did, still entails looking at a multi-sited context, not as an ethnographer who is literally moving around but as an 
ethnographer who is studying local subjects embedded in a specific system and relationships as pupils and young girls. Marcus (1998: 96) uses the concept Strategically Situated Ethnography to describe attempts to understand the subjects as well as broader aspects of the system. In order to understand how target groups negotiate the activities they are part of, I wanted to study how the girls related to the course, each other and the teachers.

In my field notes, I recorded everything that captured my interest, surprising or unexpected moments, as well as preliminary analytical memos. A graduated psychology student indexed the videos and transcribed the relevant parts verbatim. It was a collaborative process between us focused on the girls' interaction, negotiations and contestations. In the analysis process, I tried to condense the meaning and emphasize the central theme in every situation, often returning to the videos for a careful look. Some passages were dropped because they were too much focused on one single participant and thus could risk the anonymity (see Christensen and Prout 2002 on ongoing ethical considerations). I developed actor-oriented interpretations (see Geertz 1973: 14) together with second-degree interpretations (Fangen 2005: 228), where I distanced myself and brought in relevant contexts and theories.

The analytical procedures resulted in identification of two parallel processes in the interaction between the girls, the course and the teacher. The first process was characterized by a resistance on the part of the girls to the course's focus on negative 
thoughts. The second was characterized by the girls' transformation of the course. In a collective alteration, the girls and the teachers redefined 'the problem', from being individual negative thoughts, as stated in the manual, to concerning relational issues, and the 'solution of the problem' from being about changing inner thoughts to a focus on seeing each other and dealing with relationships and circumstances.

In order to listen to the girls' voices (cf. James 2007) and to fuel my immature analysis (cf. Gallacher and Gallagher 2008), I returned to the school one year after the course. One girl who had been rather quiet in the classes was now the most active of the five girls who attended. Her and the others' comments strengthened the analysis and helped me see even more clearly their interest in the course as well as their insistence on changes.

\section{Resisting negative thoughts and general problems}

During the course, the girls reacted to several paradoxical situations. The first is the fact that they are being asked to come up with negative thoughts while at the same time being told that positive thinking is what is most important. The following excerpt is from the very first class. Here the teacher presents the rules for the classes: $:^{i i i}$

we're not supposed to end up focusing on things that are a bit difficult and things that are, boring and, negative, but we should try to think positive /---/ so that we try to use what we've learned in, DISA, and make it positive do you 
see, do you understand what I mean, that you mustn't end up like (dramatically with darker pitch) 'oh damn I think this is so hard' and then we're in, something negative, but if we think like this instead, so that's rule number one, focus on the positive.... can anyone give an example, of something you complain about? (the girls are quiet)

Directly after telling the girls about the need to focus on the positive, the teacher asks them to give examples of things they complain about, all in accordance with the manual. The teacher's effort to explain this to the girls and to engage them is met by silence. As a result, the teacher speaks most of the time by following the manual or giving examples from her own experience. While this is going on, the girls put handouts in their files, tap their pens, yawn and rock in their chairs.

Three weeks later, the teacher and the girls are struggling with the same sort of exercises; they are to identify negative thoughts so they can turn them into something positive.

TEACHER: so I thought we could help each other and come up with some negative things

JOSEFIN: I have almost no negative thoughts... ever... any time, my head is pretty much empty (laughs) /---/ 
TEACHER: if you haven't got any negative thoughts of your own maybe you can practice coming up with things... things that girls your age could possibly think /---/ what could a... girl of 13, 14 possibly think as a negative thought, so we can help each other out, we can come up with some (everybody sits quiet)

In order to carry out the exercise, the teacher asks the girls to imagine what negative thoughts a girl their age might possibly have. Ten minutes later, the teacher is still trying to get the girls to give their own examples of negative thoughts, but she gets no answers. In trying to deal with a rather paradoxical situation, she tries to modify the word negative and asks the girls if they would like to tell 'a secret' or 'something nice'. If the girls' responses were silence before, now they speak out. Hilma states quickly that she does not have a secret. Josefin explains that she has one, but that it is a bit private. Mari just says no.

But what would happen if they were to talk about their difficult experiences and thoughts? In DISA, getting participants to bring up examples of negative thoughts constitutes a delicate balancing act. The manual for the group leader clearly states that the course is not therapy and not a forum for discussing experiences of depression. If someone seems to have depressive symptoms, the leader is told to refer them to professionals. The strategy in this balancing act is to use examples that could be problems. Coppock (2011) argues that the shifted focus from 'problems' to 'potential 
problems' in child welfare has its roots in efforts to control 'risky' childhoods, and such developments may weaken rather than support children's agency.

The 'potential problems' in the DISA manual mostly concern the body and appearances. This is the case with half of the manual's eight comic strips with illustrations of negative thoughts. In accordance with this focus, the teachers' own negative examples often deal with the body. In the transcripts there are examples such as 'being too fat' or 'late to develop', 'having dull clothes' or 'envying people who have nice clothes and are good-looking'. One of the comic strips shows two girls trying on bras, discussing their poorly developed breasts and stating: 'Nobody looks at me' and 'I'll probably never go out with anyone'. The examples focus on concerns about appearances, popularity, social approval and heteronormativity. In line with Walkerdine (1990), we could say that the course provides a context in which specific kinds of thoughts and positions are produced for women. Moreover, young women are constructed as 'youth at risk' (Wishart et al., 2006). Girls understand DISA as implying that they are expected to have problems, as Kvist Lindholm (work in progress) finds in her interview study. During the classes I observed, the girls resist discussing potential thoughts about their bodies.

The aim of the course is to help the girls acquire positive thinking skills - to help them scrutinize their thoughts, write about them, and work on them. This is what Rose (1996) describes as psychological techniques devised by experts to work upon the self, often with the body as a key site (Rose, 2001: 18). According to Rose's critical perspective, 
being a pupil in school today has become a psychological and even a therapeutic activity. Following Rose, psycho-educational courses such as DISA connect specific 'routines, habits and techniques' and work to the individual's obligation to search for happiness and self-realization (Rose, 1996: 38). Similarly, interviews with girls participating in DISA show that they feel they are required to be positive and happy (Kvist Lindholm, work in progress). The girls are subordinated to different means of governance, but at the same time they find creative ways of overcoming them (cf. Biehl et al., 2007; James, 2010). The analysis shows that, by transforming some of the activities, the girls assert that it is possible and necessary to take into account the context and actual problems. In collaboration with the teacher, they shift the focus to difficulties that concern interaction and suggest solutions that promote cooperation and change in the circumstances, as obvious in the second process.

\section{Renegotiating the manual and transforming the strategies}

There are four activities in the DISA course in relation to which the girls are active and responsive. Two of the activities are taken from the manual and two are introduced by the teachers. In these activities, the girls and the teacher together create something they find meaningful.

\section{Seeing each other}

First of all, the girls are enthusiastic about bringing homemade cakes and soda to class, and on the teacher's initiative they introduce refreshment breaks in the course. The girls 
create a sort of a table out of a waste basket and an upside down flipchart. Now and then the teacher makes it clear that they cannot just have fun; they have to work as well. Sometimes the girls suggest taking refreshments and working at the same time. On such an occasion (March 8), the teacher says after a while: 'Should I point out a contrast to what I think we're doing right now'. She reads a comic strip and illustrates a 'depressive posture' with her body. The girls pour the soda for each other while this is going on. Once more, the teacher says that the girls look quite the opposite of the boy in the comic strip who is slumped over; she says it is really great to see the girls today. These contrasts appear now and then during the course; the girls and the teacher are having a good time together but they are supposed to be working, which means identifying negative thoughts and dealing with them.

Sometimes the girls become engaged in trying to understand concepts in the manual such as 'depressive' or 'unreasonable thoughts'. For eleven minutes on March 8 they have a lively discussion, albeit signaling ‘conceptual confusion’ (Hacking 1999), while they continue eating and drinking. The girls both adhere to the course and transform the circumstances into something more like a social gathering.

\section{Relationships and interests}

The second exercise that engages the girls is called 'sharing, iv . One of the group members is to bring something personal to the group and share it with the others, something that means a great deal to her, something positive, according to the manual. 
The procedure for doing this turned out to be showing one's mobile phone pictures, a practice the teacher used when she introduced 'sharing'. When Josefin talks about a picture of her best friend she reveals that she has only one friend, and that 'she's the only one who understands me /---/ we've got almost the same problems'. On another occasion Elin tells about a difficult experience in her family: 'this picture means a lot to me because it's my grandfather, but he died six years ago /---/ he was very kind and always willing to help me or everyone'.

In this exercise the girls bring in their own concerns and glimpses of their personal experiences, but not only positive ones as requested. Through four classes the girls have been asked to talk about their negative thoughts, in order to change cognitive structures, without responding, but all of a sudden they are engaged in an exercise where they can talk about things that are of interest to them. Moreover, the girls manage to expand the time used for the slide show and discuss photos of friends, birds, relatives, sport teams and nature sceneries. The girls make 'sharing' into a central instead of a peripheral and concluding exercise. They share their interests and draw attention to their actual problems, abilities and resources, rather than discussing the potential and general problems the manual brings up concerning their mental activity.

\section{Complicating communication}

The third kind of exercise the girls engage in is communication exercises that are included in two of ten classes. They do not seem to appreciate these exercises as much 
as they appreciate 'sharing', but they do become engaged because they recognize the situations and have their own ideas about how communication works between girls their age. In one exercise, they learn three rules for being an active listener: to reiterate what the other person has said, show that you have understood, and be neutral. The girls, however, prefer alternatives where you 'pep up' the other person rather than being neutral. The teacher presents the 'right' answer, but they still argue that 'pepping up' is good. It seems as though the manual's rules for being an active listener are far from the daily communication in which the girls are involved. They do not see their role in a communication situation as someone who listens, interprets and retells what they have heard. They listen and react, often spontaneously, to what they hear. The exercise seems to focus on therapeutic or adult responsibilities instead of the here and now, on girls as 'becomings' rather than 'beings' (Qvortrop, 1994). According to Coppock (2011), psychotherapeutic education focuses on the future adult young people are expected to be instead of on contributing to their agency.

Another communication exercise that engages the girls is one that discusses 'behaviors most people appreciate', according to the manual. There is a list of behaviors that are believed to convey a kind and open attitude: make eye contact, smile in a relaxed manner, look positive and say something about yourself. The girls are asked to mark their bad habits on another list with examples such as do not smile, look uninterested, slumped posture, speak too little, ignore others, cry often. When the teacher asks them 
to tell what they have marked, Mari says: 'pooh I fiddle with my hair but that's because I'm thinking not because I'm unsociable' and Hilma declares: 'I don't think I smile very often, but listen it's not that I show with my face that I'm uninterested'. Their reactions call into question whether these listed bad habits actually obstruct contact with other people. Moreover, they question whether it is possible to discuss communicative behavior out of context. Fiddling with your hair or not smiling probably does not hinder contact with close friends, but it may be a hindrance in a job interview.

After a longer discussion, Elin shifts the discussion over to a real problem that concerns herself and Hilma.

ELIN: I've got something to say about Hilma, listen nothing like a nasty thing, but /---/ when we're sitting on the bus to school, she ignores me all the time, 'cause she sits and plays with her mobile

HILMA: I don't ignore you, I'm just unsociable /---/

TEACHER: this is very exciting 'cause here you both are in the same situation, both of you are familiar with it, Elin feels she's being ignored and you think... that you shut yourself off /---/ and then the question is whether you can accept that she sits there and shuts herself off

ELIN: yeah 
TEACHER: (to Hilma) can you do something so she doesn't feel ignored

HILMA: yes change seats $\mathrm{x}$ sometimes I speak to her

ELIN: yes sometimes /---/

HILMA: but I usually answer after a while

ELIN: yeah

Elin talks about her problem riding the bus with Hilma. The teacher asks them to be tolerant of each other's preferences. When the girls turn to a real problem in their interactions with each other, the suggestions in the manual to 'smile in a relaxed manner' or 'look interested' seem to be somewhat remote. The communication the girls are engaged in is more complicated and differentiated than adhering to a list of 'behaviors most people appreciate'. The list speaks of a simplistic picture of communication, and highlights the individual's behaviors and failings (cf. Hoffman 2009). Elin's example, on the contrary, emphasizes the relational context the girls are part of.

\section{Interactional problems}

Finally, the fourth exercise the girls become absorbed in are co-operation exercises introduced by the teacher. ${ }^{v}$ On April 12, the teacher presents an exercise on how to say no and to mark when someone comes too close. The girls and the teachers are in the 
middle of the floor and are trying to find different ways to stop someone who is approaching. Hilma says that she feels uncomfortable and the teacher asks how she can show that. Hilma crosses her arms and leans back. They change partners and cooperate in a lively fashion. They discuss how near you can come and how far you may have to go to stop someone. Now and then they laugh, hug or rest on someone's lap. After the exercise, the teacher asks whether this can happen in real life and Sara talks about a difficult experience:

SARA: I have been the vic-, it happened to me

TEACHER: yes, do you want to tell us

SARA: it was on New Year's

TEACHER: what happened then

SARA: it was like this, lots of dirty old men (laughs), and I was sitting by a friend's computer and he comes in and comes close to me and I say 'that's enough now, stop', he comes close to me like this (demonstrates on Pia) I thought it was a bit unpleasant, but I said 'stop' and he said 'no I'm not going to stop', finally I pushed him aside and then he pulled me down on the floor and like this, then I kicked his legs away

TEACHER: oh no God what a terrible experience 
Sara is on her way to saying that she has been 'the victim' of something, but changes to 'something that happened' to her. She seems to have been influenced by the exercise they just did. In telling her story, she uses the strategies she has learned: to say stop and physically mark her boundary. She presents herself as is in charge, not as a victim. The focus in the course is shifted from learning 'behaviors most people appreciate' to understanding when someone has come too close, how to say no and take charge of difficult situations. Not even the teacher manages to use the manual's advice on being an active listener. Instead of recalling what she has just heard and being neutral, she exclaims 'God what a terrible experience'. Before the girls leave, the teacher gives them homework where they are to challenge themselves to say stop to someone who has come too close. The class ends with interactional problems that the girls can recognize from their own experiences.

In DISA, a young girl's problem is defined as one of individual self-control (cf. Hoffman, 2009 about SEL). The episode above, however, shows that there are circumstances that influence a young girl's mental health that cannot be changed by changing one's thoughts. Moreover, it indicates that cognitive methods for dealing with negative thoughts could be replaced by exercises designed to work on relational and situational problems with a view to dealing with interaction and strengthening the individual. 
Throughout the classes, the girls constantly relate to relations and interaction instead of individual thoughts. During the next-to-last class, an alternative to the procedure of replacing negative thoughts with positive ones comes up. Hilma says that she was in a bad mood in the morning, but after she saw Pia it changed. The teacher wonders what brought about the change and Pia says: 'I made it change'. The teacher is very interested and asks what Pia did and Pia says that she does not know. Then Hilma stretches out her arms and exclaims 'I saw her' with a big smile on her face. The teacher asks whether it was that easy to change her mood and Hilma says 'yes'. The episode suggests that change comes from seeing each other. Instead of individual cognitive strategies, the girls find relational strategies for changing their mood. Their preference for togetherness is symptomatic of the four activities the girls take an active part in throughout the course. Many of the exercises in DISA point to individual insufficiency that is to be dealt with single-handedly (cf. Löf, 2011). The girls' interest in interactional problems, however, question the individualization that characterize educational policy in late modern childhood (Prout 2000), and points to a more contextbased, relational, and situational view of problems and their solutions in educational programs (cf. Hoffman, 2009).

\section{The critical potential of subjectivities}

I will end the article by discussing the critical potential of these results and applying it to the use of manual-based courses in the schools. In order to evaluate interventions, we 
need to understand more about subjectivities and experiences in specific contexts and situations (Kleinman and Fitz-Henry, 2007). Collective symbols and subtle forms of power that permeate everyday life are open to change. Our senses and subjectivities 'return to those symbols and interactions, reconfiguring, repatterning, and sometimes even completely reinterpreting them' (Kleinman and Fitz-Henry, 2007: 53). The girls are influenced by the course and subject to its routines and discourses, but the way in which they participate transforms the realities they are part of. By exploring the girls' acts of insistence, we can better understand what a course like DISA creates and how the girls reinterpret it.

DISA starts from the intention to supply girls with tools for handling their existence and gaining self-confidence. In order to teach girls how to deal with negative thoughts, however, an activation of such thoughts is needed. Paradoxically, the thoughts that are to be activated are exactly what the course is supposed to help the girls avoid. When the teachers and the manual insist on getting hold of negative thoughts, the course presents a view of girls as having problems. Moreover, the course proposes that problems are individual deficits independent of the relational contexts the participants are part of (cf. Hoffman, 2009). The very foundation of the course - namely teaching teenagers cognitive methods for dealing with negative thoughts - seems to be misplaced when it targets a group of school girls irrespective of their psychological health. Spotlighting the messages embedded in the manual, and what happens when DISA is practiced, offers an 
insight into the kinds of subjectivities DISA will tend to produce, namely young girls who are aware that they have problems and who turn their focus and performance inwards on themselves. Thus, this spotlighting may call into question the use of manuals based on CBT in courses for school girls.

However, the course I followed was meaningful to the girls. They had the privilege to meet, on a regular basis, each other and an interested teacher, all of whom were attentive to their needs and possibilities. The teachers constantly used the manual, but at the same time, they noticed the atmosphere and incidents in the group and allowed the girls to take action. The girls, for their part, were benevolent, engaged and flexible course members. They accepted the conditions but not the work they were supposed to do. Their possibility to take part in shaping the course depended on their resources and the teachers' willingness to enable them to act (cf. James, 2010).

The girls expanded the space and time for things of importance to them, and in so doing they created a context for exercises that were otherwise isolated. They resisted the focus on potential negative self-perceptions and thoughts, and turned the spotlight on their actual problems and resources. The main result reveals the girls' insistence on interaction. They promoted communication and cooperation, and would rather work on their relationships than on their inner states. In collaboration with the teacher, the girls turned DISA into something new. In fact they practiced the very opposite of what they 
were supposed to learn; instead of changing their inner states, they changed the circumstances.

There is a potential for criticism in these acts. The manual states that 'it is only possible to change one's own actions and thoughts, not what is happening outside us'. The aim, I suppose, is to encourage course participants to be in charge and not consider themselves victims of circumstances. But the girls in the study deal with much more than their own actions and thoughts. They have to deal with complex situations in school, together with friends, and in their families. The inner lives of subjects are always part of social and political processes that cannot be left out.

As I mentioned previously, the present findings may call into question the usefulness of universal manual-based courses. The course changes with different participants and leaders, as the study shows, which is something the manual encourages as long as change stimulates more exchange between the participants. Ironically, the fact that the courses change also demonstrates the weakness of using manual-based courses at school. If they are open for negotiations, they lose their claimed strength. However, an alternative to manual-based educational courses designed by professional health experts would be courses based on activities more in line with how adolescents actually shape how the courses are realized. The changes the girls and the teachers in the study bring about question the use of cognitive methods for changing negative thoughts and instead 
provide examples of activities that work on situational problems and deal with interaction.

\footnotetext{
'The course for becoming a DISA leader consists of three days of training, supervision and practice at one's ordinary workplace.

ii The procedures have been approved by the Regional Ethical Review Board of Linköping University (Reg. no. 2010/50-31).

iii Transcription conventions used: (text) marks transcriber comments, ... pause, $x$ or xx inaudible word or words, bold emphasis, /---/ talk omitted from the data excerpt, "text' dialogue within the story

${ }^{\text {iv }}$ Free translation from original Swedish.

${ }^{v}$ The DISA manual allows group leaders to make some small changes. Changes that encourage more exchange between participants are the most desirable. Group and role-playing exercises are given as examples.
}

\section{References}

Biehl J, Good B and Kleinman, A (eds) 2007. Subjectivity. Ethnographic Investigations. Los Angeles: University of California Press.

Christensen P and Prout A (2002) Working with ethical symmetry in social research with children. Childhood 9(4): 477-497. 
Clarke G and Lewinsohn PM (1995) Instructor's manual for the Adolescent Coping with Stress Course. Kaiser Permanente Center for Health Research, Portland. Available at: www.kpchr.org/public/acwd/acwd.html (accessed 18 January 2011).

Clarke GN, Lewinsohn PM, Hops H (1990) Leader's Manual for Adolescent Groups: Adolescent Coping With Depression Course. Kaiser Permanente Center for Health Research, Portland. Available at: www.kpchr.org/public/acwd/acwd.html (accessed 18 January 2011).

Coppock V (2011) Liberating the Mind or Governing the Soul? Psychotherapeutic Education, Children's Rights and the Disciplinary State. Education Inquiry 2(3): 385399.

Dahlstedt M, Fejes A and Schönning E (2011) The will to (de)liberate: shaping governable citizens through cognitive behavioural programmes in school. Journal of Education Policy 26(3): 399-414.

Duranti A (1997) Linguistic anthropology. Cambridge: Cambridge University Press.

Fangen K (2005) Deltagande observation. Malmö: Liber.

Gallacher LA and Gallagher M (2008) Methodological Immaturity in Childhood Research? Thinking through 'participatory research'. Childhood 15(4): 499-516. 
Geertz C (1973) The Interpretation of Cultures. New York: Basic Books.

Hacking I (1999) The Social Construction of What? Cambridge University Press.

Halldén G (2003) Barnperspektiv som ideologiskt eller metodologiskt begrepp. Pedagogisk forskning i Sverige 8(1-2): 12-23.

Heath C, Hindmarsh J and Luff P (2010). Video in qualitative research: Analysing social interaction in everyday life. London: Sage.

Hoffman, DM (2009) Reflecting on Social Emotional Learning: A Critical Perspective on Trends in the United States. Review of Educational Research 79(2): 533-556.

Jablonska B and Heinemans N (2011) Metodtrohet $i$ det främjande och förebyggande hälsoarbetet i skolan. SET- och DISA-metoden. Report, Karolinska Institutet, Sweden.

James AL (2010) Competition or integration? The next step in childhood studies?

Childhood 17(4): 485-499.

Johannisson K (1997) Kroppens tunna skal. Sex essäer om kropp, historia och kultur. Stockholm: Norstedts.

Kleinman A and Fitz-Henry E (2007) The experiential basis of subjectivity: How individuals change in the context of societal transformation. In: Biehl J, Good B and 
Kleinman A (eds) Subjectivity. Ethnographic Investigations. Los Angeles: University of California Press.

Kvist Lindholm S “Apparently I've got mental problems': when psychological treatment becomes universal preventive interventions practiced in schools. Work in progress.

Lindberg L (2011) Varför DISA metoden i tjej-grupper? Available at: www.disametoden.com/ (accessed 13 February 2012).

Lindberg L, Svensson J, Treutiger BM, Koertge J, Thomas EM (1995) En metod för tonåringar $i$ att hantera stress och påfrestningar. DISA (Depressive Symptoms in Swedish Adolescents) Gruppledarmanual/Elevmanual. Unpublished manual, Karolinska institutet, Stockholm.

Löf C (2011) Med livet på schemat. Om skolämnet livskunskap och den riskfyllda barndomen. PhD Thesis, Malmö University, Sweden.

Marcus GE (1998) Ethnography through Thick \& Thin. Princeton: Princeton University Press.

Merry SN, McDowell HH, Hetrick SE, Bir JJ, Muller N (2009) Psychological and/or educational interventions for the prevention of depression in children and adolescents. Cochrane Database of Systematic Reviews 2: 1-124. 
Orbach S (1999) Towards Emotional Literacy. London: Virago.

Prout A (2000) Children's Participation: Control and Self-Realisation in British Late Modernity. Children \& Society 14: 304-315.

Qvortrop J (1994) Childhood Matters: An Introduction in Qvortrop J, Bardy M, Sgritta G and Wintersberger H (eds.) Childhood Matters: Social Theory, Practice and Politics. Aldershot: Avebury.

Rose N (1996) Inventing ourselves: psychology, power and personhood. New York: Cambridge University Press.

Rose N (2001) The Politics of Life Itself Theory, Culture \& Society 18(6): 1-30.

SBU, Swedish Council on Health Technology Assessment (2010) Program för att förebygga psykisk ohälsa hos barn. Report 2010:202.

Swedish National Institute of Public Health (2011) Kartläggning av psykisk hälsa bland barn och unga. Report 2011: 09.

Treutiger BM (2006) Evaluation of the DISA-program (Depression in Swedish Adolescents) to prevent depressive symptoms among female adolescents. Exam paper, Karolinska Institutet, Sweden.

Valentine K (2011) Accounting for Agency. Children \& Society 25: 347-358. 
Walkerdine V (1990) School girl fictions. London: Verso.

Wickström, Anette (2008) Kärlek I virusets tid: att hantera relationer och hälsa I

Zululand. PhD Thesis, Linköping University, Sweden.

Wishart D, Taylor A and Shultz L (2006) The construction and production of youth 'at risk'. Journal of Education Policy 21(3): 291-304.

Zetterqvist Nelson K (2012) Barns perspektiv i forskning om barns psykiska hälsa förhållningssätt och utmaningar. The Journal Barn 1: 9-22. 